\title{
How to Win Friends and Influence Industry Collaborators
}

\author{
Alan Perks ${ }^{1}$, Rozalina Dimitrova ${ }^{2}$ \\ ${ }^{1}$ Engineer-in-Residence (Alan.Perks@uottawa.ca); ${ }^{2}$ Replacement Professor \\ 1,2 Department of Civil Engineering, University of Ottawa, Canada
}

\begin{abstract}
The Capstone process helps prepare Civil Engineering students for a rapidly evolving practice now facing many urgent social, economic and environmental pressures. Recent experience in identifying suitable capstone projects and working effectively with industry collaborators and student teams will be discussed. The project portfolios will be reviewed, and the approach to recruiting and retaining collaborators, working with faculty advisors, and supporting student teams will be summarized. Lessons learned from all these perspectives provided important adjustments to the uOttawa approach, which in past semesters has succeeded in providing all students in as many as to 25 teams in a semester with an industry collaborator and a valuable opportunity to enhance their skills in communications, planning, creative engineering solutions, and interdisciplinary teamwork.
\end{abstract}

Keywords: Capstone, Interdisciplinary, Industry, Collaboration.

\section{INTRODUCTION}

A review of the engineering education literature indicates that the transition to experiential learning, as embodied in the Capstone process, has been going on for 50 years now (Lye and Bruneau, 2011) demonstrating that the increased student-faculty-industry collaboration not only strengthens professional Engineering education, but also increases student awareness and appreciation of the significance of their professional work to society in general. Other researchers (Symonds and Britton, 2012; Behdinan et al., 2015) have demonstrated the organizational and curriculum features that can enhance multidisciplinary design skills through exposure to an industrial setting, and also highlight the role played by Engineers-inResidence in terms of industry outreach and student mentorship. Regular reviews and assessments of Capstone design based approaches (Todd et al., 1995; Zancul et al., 2017) have been carried out to provide additional insights into the Capstone process, lessons learned and suggestions for future incorporation into design courses in engineering.

Based upon the research conducted, the Department of Civil Engineering at the University of Ottawa tries to prepare all its $4^{\text {th }}$ year undergraduate students for entering their profession with a problem-based learning 
experience in collaboration with practicing civil engineers and engineering offices. As many as 20 teams of 4-6 students undertake their Capstone project and report in each term, capping their $4^{\text {th }}$ and final year of the civil engineering curriculum.

Capstone projects are developed in collaboration with business, industry and government in the National Capital Region, including consulting firms, manufacturers, contractors, federal and provincial agencies, municipalities and conservation authorities. Increasingly, video conferencing systems enable projects to be undertaken across Canada with the help of willing collaborators.

By working in interdisciplinary teams in collaboration with practicing civil engineers and technologists, students learn to apply academic knowledge in an entrepreneurial manner and to develop the teamwork, problem solving and communication skills essential for career professional development.

\section{HOW IT WORKS}

The departmental faculty try to ensure that the Capstone projects are interdisciplinary and reflect the full range of civil engineering sub-disciplines as much as possible - structural, geotechnical, water, environment, roads and transportation, as well as engineering economics and project management (Rennie and Dimitrova, 2017).
Initially project "tenders" are circulated, to which the student teams respond with a brief letter of interest. The professor responsible for the tender usually acts as faculty supervisor and the industry collaborator acts as a mentor to the project team. However, student teams are free to develop their own project tender to suit their unique interests and utilize their own contacts in engineering firms.

Each Capstone team is expected to produce a proposal and a feasibility report in the first term, including design methodology, alternative solutions, preliminary cost estimates, structured decision making process for selection of preferred alternatives, and a project work plan, which is then developed into the final design report during the second term. Students communicate their design projects through the written proposal and preliminary reports, and through oral presentation of the preliminary report which also serves as a design progress report.

In the first semester of the design course (CVG 4001) analytic tools useful in the design process are introduced, including: project management procedures such as network logic diagrams and Critical Path Analysis (CPA), PERT (Program Evaluation and Review Technique); idea generation techniques such as brainstorming; selection methods such as decision matrices; and optimization procedures such as linear 
programming and genetic algorithms. Students are also introduced to software commonly utilized for management and presentation of engineering designs (e.g., Microsoft Project).

The second half of the design course (CVG4907) is largely self-taught, and students are expected to begin working on the detailed design for their project with the support of their faculty supervisor and in communication with their industry collaborator. Below is a summary of student activities during both semesters of the capstone design course.

\begin{tabular}{|l|}
\hline \multicolumn{1}{|c|}{ Student Activity CVG 4001 (1 $^{\text {st }}$ term) } \\
\hline Project Tenders; Student Teaming; \\
\hline Inception Meeting \& Discussion \\
\hline Prepare Project Proposal \\
\hline Conduct Preliminary Study \\
\hline Preliminary Study Report \& Presentation \\
\hline \multicolumn{1}{|c|}{ Student Activity CVG 4907 (2 ${ }^{\text {nd }}$ term) } \\
\hline Conduct Detailed Analysis and Design \\
\hline Progress Report, Review of Results \\
\hline Capstone Design Report \& Presentation \\
\hline Presentation to Collaborator Agency \\
\hline Student Competitions, $u$, PEO, CSCE \\
\hline
\end{tabular}

\section{WINNING FRIENDS}

Ideally, Capstone projects represent "win-win" situations whereby the collaborators may also receive valuable analysis and preliminary design support in their own areas of interest. The value of engineering input from a team of 6 students working over a 24-week academic year is conservatively estimated to be about $\$ 45,000$ to the collaborator. Several considerations come into play when recruiting practicing civil engineering collaborators.

There is always an interest expressed in contributing to the profession by potential collaborators. The importance of Civil Engineering to society in general, not only to client needs, is always a central concern in preparing students for their careers.

Secondly, time is indeed of the essence. In modern engineering workplaces, partly driven by the speed of modern information technology, the pace of practice is often "fast and furious". Student teams are expected to respect the collaborator's time and focus their efforts and communications, and keep in touch effectively.

The win-win situation mentioned above often is realized when the student project can actually provide useful research and technical analyses that may contribute to a collaborator's ongoing client projects. Sometimes this has also provided an opportunity for a student team to make a "brown bag" presentation to the collaborator's company, or even to its client. In other situations, 
the Capstone project may be picked up by local media to highlight a project of local interest.

The Department endeavours to keep in touch with all collaborators as the academic years progress, simply to keep them informed and provide an opportunity to discuss rewards and challenges of the Capstone process. Many collaborators have mentored student teams for 5 years.

Finally, most industry collaborators recognize that working with a Capstone team and attending their presentations represents a valuable "job fair" opportunity. All collaborators are invited to attend the feasibility study presentation (first term) and the design report presentation (second term) and the result has indeed been job offers extended to students from the collaborator's firm.

\section{BEING CREATIVE}

More than ever, given the challenges facing global human society, it is essential to foster creativity and innovation by means of the Capstone process (a, d). Creativity and innovation can be achieved in different ways: using new technologies to provide better engineering designs, for example LEED building designs; or, by using old technologies to achieve more efficient infrastructure, such as building new upstream aqueducts to convey water to municipal treatment plants that can be operated by gravity instead of by pumping, thereby saving large amounts of energy.

Recent uOttawa Capstone projects have demonstrated innovation and creativity (Perks and Rennie, 2018; Perks et al., 2018). For example, rather than simply designing a larger sewer system for an eastern Ontario town called Wendover, a capstone design team proposed and designed a smart metering and pumping system (STEP) to maximize capacity of the town's overextended sewer system. Improvements to the Cambridge Bay Airport in very difficult climate and terrain, were also completed by a Capstone team. Seismic retrofit of heritage buildings to bring them up to speed with the requirements of current codes breathes new life into them while preserving their heritage aspects. Another team worked on better methods to estimate forest hydrologic retention parameters, a significant research contribution to hydrologic modelling in Canada. A Tsunami Shelter project for the Municipality of Tofino, BC, the resulted in the municipality funding further design work by the student team. New techniques for Timber construction were explored. And the Prince of Wales Bridge Upgrade and associated Community Train Station project is a significant Capstone project that was mentioned recently in the Ottawa Citizen. 
Attached as Appendix A is a recent edition of the Capstone News, outlining other projects and activities related to the Capstone process in the department.

\section{LESSONS LEARNED}

On the positive side, the Capstone projects generate much interest and enthusiasm among both the students and the collaborators (Rennie and Dimitrova, 2017). As mentioned above, collaborators often attend the final team presentations, and are usually very impressed with the work of their mentored team. The team presentations can indeed serve as a most effective "job fair" for industry collaborators and other interested working professionals.

Also, many of the selected projects do focus on the primary business interest of the collaborators, and either advance work already going on in the organization, or enable the organization to address a problem they have been unable to address prior to the Capstone opportunity presenting itself.

Most student teams work effectively together. Out of say 15-20 teams working at the same time, perhaps 1 or 2 teams will experience technical or interpersonal issues that may require adjustments and assistance from the course instructor or the Engineer-in-Residence to help resolve.
There is often a preference among many students for more technically focused projects in the area of structural or geotechnical design, without other related components. Where a team is primarily interested in one technical area, the team and/or the collaborator can often adjust the project to suit while maintaining the interdisciplinary aspect of the project.

The level of complexity of some capstone projects put forward by the industry collaborators, often exceeds the knowledge and skills of the student teams. Further independent research, data collection, site visits and even experimental work are sometimes required from students to successfully complete their capstone projects. Many of them refer to the capstone project as the "most educational experience" in their undergraduate studies.

Sometimes, student teams do require assistance in negotiating with collaborators to adjust the project to best meet the interests of both, as it can be intimidating for some to become involved with very busy engineering professionals and offices at this stage.

Initially, collaborators were recruited with their own projects, drawings and databases that enabled students to proceed. This is perhaps the most time consuming role for the collaborator, but it is essential for the success of the program. 
More recently, student teams and/or their faculty advisors have devised their own projects out of personal interest and experience, and collaborators are recruited to act simply as professional mentors wherever possible. The goal is every team works with a collaborator.

Nevertheless, there still may be difficulties in identifying faculty advisors sufficiently familiar with every collaborator or student project brought forward. Now, the specific research interests of faculty supervisors within the department are discussed prior to each term so that discussions can be had with potential collaborators to include some faculty preferences into a proposed project, which can usually be achieved.

Lastly, it is best to introduce 3rd year engineering students in some detail to the Capstone experience as many are not fully aware of how a successful Capstone experience can be in launching their civil engineering careers.

\section{WHAT LIES AHEAD?}

As the Capstone process is intended to prepare young engineers for future practice, the questions posed during the 2015 Civil Engineering Triennial Summit in London regarding the challenges facing engineering are worthy of consideration. Are we past the climate change tipping point? Why must civil engineers act now? Are we up to the task? How we will manage with
11 billion people in the years to come (Perks 2017; Perks et al., 2017; Perks and Rennie, 2018; Perks et al., 2018)? The 2018 CSCE Annual conference in Fredericton also focused discussion on where the profession may be missing the boat on key issues, and what lies ahead if not addressed. There are many views on "what lies ahead" for our profession and for society. But it is unlikely to be met with a business as usual approach to engineering, infrastructure, and energy utilization. Under any scenario of future energy sources, availability and use, Civil engineering solutions must be designed for the lowest possible resource depletion and carbon footprint in meeting society's needs.

The Capstone process at the University of Ottawa, and across Canada, helps to provide Civil Engineering students with the skills and experience not only to build a successful career in the practice, but also to help meet the needs of Canadian and global human society in the most sustainable manner which is, in fact, the founding precept of the profession of Civil Engineering.

This can be demonstrated at the University of Ottawa's Civil Engineering Department by a number of final observations. The ongoing feedback has generally been positive from all participants, students, faculty and industry collaborators. Numerous unique and award winning Capstone projects have been undertaken 
over the last several years: creative decentralized water systems, low impact development urban roadways and servicing, rehabilitation of heritage buildings, renewal of a rail bridge in Ottawa under the MOOSE Consortium, expansion of an Ottawa Library for the City, and a Tsunami Relief structure for Tofino, BC. A number of these projects provided useful engineering inputs used by the collaborators to advance their projects, especially the Tsunami project, which received ongoing funding from the collaborator. Numerous Indigenous and First Nations housing, roads, airport and water projects were completed (as far north as Cambridge Bay) by student teams working in collaboration with Indigenous \& Northern Affairs Canada (now Indigenous Services Canada), providing useful and sustainable solutions to northern communities working with local communities. One final point is that after the Capstone reports and presentations have been made, students are clearly better prepared to enter the industry as working professional, and some have been hired by the collaborator agencies they worked with, a final source of confirmation regarding the success of the uOttawa Capstone programme.

While the students are not tracked formally after leaving the University to embark on their careers, informal discussions with graduates and collaborators indicate that teamwork, communications and judgement has been enhanced by the process, and collaborators usually continue with new teams each semester. The First Nations and northern community projects have had the extra return of increasing all participant's awareness of the needs of small remote communities, and hopefully will attract first nations and indigenous youth into the profession of engineering, which is presently a significant gap. A periodic newsletter to increase the awareness of the Capstone process at uOttawa is produced, and will be more widely circulated to help achieve this goal.

\section{REFERENCES:}

Behdinan, K., Pop-Iliev, R., Foster, J. (2015). What constitutes a multidisciplinary capstone design course? Best practices, successes and challenges. In Proceedings of the Canadian Engineering Education Conference, University of Calgary, Calgary, AB, June 8-11, 2014. (https://doi.org/10.24908/pceea.v0i0.5940).

Lye, L., Bruneau, S. (2011). Industry-based capstone design projects: Memorial's forty years experience. In Proceedings of $C D E N / C 2 E 2$ Conference, McMaster University, Hamilton, ON, July 27 - 29, 2009.

(https://doi.org/10.24908/pceea.v0i0.3722).

Perks, A.R. (2017). Rising Above Routine Practice. In Proceedings of the International Conference on Sustainable Infrastructure, ASCE, New York City, USA, October 26-28, 2017. (https://doi.org/10.1061/9780784414811.ch21).

Perks, A.R., Rennie, C., Dimitrova, R. (2017). The Capstone Experience. Canadian Society for Civil Engineering Annual Conference, Vancouver, BC, May 31-June 3, 2017. 
Perks, A. R., Rennie, C. (2018). A Bridge Too Far. J. Prof. Issues Eng. Educ. Pract., 144(3). (https://doi.org/10.1061/(ASCE)EI.1943-

5541.0000368)

Perks, A.R., Rennie, C., Dimitrova, R. (2018). Here and Now. Canadian Society for Civil Engineering Annual Conference, Fredericton, NB, June 13-16, 2018.

Rennie, C., Dimitrova, R. (2017). CVG 4001 Introduction to Civil Engineering Design. Department of Civil Engineering, University of Ottawa, ON.

Symonds, J.M., Britton, R. (2012). Engineers-inResidence - A Bridge to the Future. In Proceedings of the Canadian Engineering Education Association Conference, University of Manitoba, Winnipeg, MB, June 17-20, 2012. (https://doi.org/10.24908/pceea.v0i0.4616).

Todd, R., Magleby, S., Sorensen, C., Swan, B. (1995). Survey of Capstone Engineering Courses in North America. J. Eng. Educ., 84(2).

(https://doi.org/10.1002/j.2168-

9830.1995.tb00163.x.)

Zancul E., Durao L., Lopes R., Nakano, D., Blikstein, P., Majzoub, G., Dalmon, D. (2017). An Empirical Study of Design-Based vs. Traditional Approaches in Capstone Design Courses in Engineering Education. J. Eng. Educ.,33(5), pp. 1543-1560. 